\title{
Omega-7 inhibits inflammation and promotes collagen synthesis through SIRT1 activation
}

\author{
In-Bong Song ${ }^{1} \cdot$ Hyejung Gu${ }^{1} \cdot$ Hye-Ju Han ${ }^{1} \cdot$ Na-Young Lee ${ }^{2} \cdot$ \\ Ji-Yun Cha ${ }^{2} \cdot$ Yeon-Kyong Son ${ }^{2} \cdot$ Jungkee Kwon $^{1}$
}

Received: 16 March 2018/ Accepted: 21 May 2018/Published online: 1 June 2018

(C) The Korean Society for Applied Biological Chemistry 2018

\begin{abstract}
Excessive accumulation of reactive oxygen species (ROS) during oxidative stress accelerates the skin aging process. ROS stimulate inflammatory processes in the skin, leading to activation of matrix metalloprotease-1 (MMP-1). Silent information regulator 1 (SIRT1) controls a broad range of cellular functions including the expression of MMP-1. Omega-7 fatty acids such as palmitoleic acid have many beneficial effects on health, including improvement in cardiovascular risk factors and increased insulin sensitivity. However, the effectiveness of omega-7 fatty acids (herein referred to as omega-7) related to skin aging, characterized by the degradation of collagen and loss of elasticity, remains unclear. We here investigated the effects of palmitoleic acid, a representative omega-7, on collagen regeneration through its ability to activate SIRT1 and inhibit MMP-1 in the presence of hydrogen peroxide $\left(\mathrm{H}_{2} \mathrm{O}_{2}\right)$-induced oxidative stress in human $\mathrm{HaCaT}$ cells. SIRT1 activation by omega-7 decreased signaling levels of nuclear transcription factor kappa B (NF-kB) and inflammatory cytokines. However, inhibition of SIRT1 by sirtinol counteracted the advantage effects of omega- 7 in $\mathrm{H}_{2} \mathrm{O}_{2^{-}}$ treated $\mathrm{HaCaT}$ cells. In addition, omega-7 significantly counteracted the decrease in collagen abundance and loss of elasticity induced by $\mathrm{H}_{2} \mathrm{O}_{2}$. Consistent with this observation, omega-7 significantly decreased $\mathrm{H}_{2} \mathrm{O}_{2}$-induced upregulation of MMP-1 in HaCaT cells. Together, these
\end{abstract}

Jungkee Kwon

jkwon@jbnu.ac.kr

1 Department of Laboratory Animal Medicine, College of Veterinary Medicine, Chonbuk National University, Iksan, Jeonbuk 54596, Republic of Korea

2 R\&D Team, Food \& Supplement Health Claims, Vitech, Jeonju, Jeonbuk, Republic of Korea studies suggest the potential efficacy of SIRT1 in collagen regeneration and indicate that omega- 7 is a possible functional food to improve skin health for the prevention of aging.

Keywords Anti-inflammation - Collagen regeneration . Omega-7 · Oxidative stress · Silent information regulator 1

\section{Introduction}

Oxidative stress is considered as a main factor that cause toxic effects through the generation of free radicals and can cause disruptions in normal cell function [1]. In the skin, oxidative stress is generated by various external stimuli such as excessive exposure to UV, environmental toxins, and heat [2] and leads to the production of reactive oxygen species (ROS) [3]. ROS products can accelerate skin aging by decreasing collagen regeneration and elasticity while simultaneously increasing the abundance of inflammatory factors [4]. Collagen regulation factors such as metalloproteinase-1 (MMP-1) and pro-collagen type 1 (PCOL1) have important roles in oxidative stress generated in the skin [4]. Likewise, collagen degradation by oxidative stress is a major feature of damaged skin, and collagen regulation factors are used as a distinctive marker of oxidative stress and inflammation in aging skin.

Silent information regulator 1 (SIRT1) is the most extensively studied members of the class III histone deacetylase family in mammals. SIRT1 plays a key role in various physiological processes such as aging, inflammation, senescence, and apoptosis [5]. Moreover, SIRT1 regulates inflammatory responses through deacetylation of nuclear transcription factor kappa B (NF- $\mathrm{BB})$, a major 
factor associated with the regulation of pro-inflammatory cytokines [6]. Along these lines, external stimuli such as UV irradiation, environmental toxins, and heat reduce SIRT1 expression as demonstrated in human keratinocytes [7].

Palmitoleic acid (16:1, Cis-9-hexadecenoic acid) is an omega-7 fatty acid (herein referred to as omega-7) found in cold-water fish and plants such as macadamia and sea buckthorn berry [8]. Various studies have reported that omega-7 is associated with a number of beneficial effects such as improved cardiovascular risk [9] and increased insulin sensitivity [10]. Similar to omega-7, omega-3 unsaturated fatty acids inhibit inflammation by activating the SIRT1 pathway in mouse microglia cells [11]. In addition, omega-3 has demonstrated to increase SIRT1 gene expression in coronary artery disease as well as to generate antioxidant effects [12]. Likewise, omega-9 unsaturated fatty acids have been shown to ascent rates of complete fatty acid oxidation by SIRT1-PGC1 $\alpha$ complex activation in skeletal muscle cells [13]. However, the effects of omega-7 with respect to SIRT1 and skin aging have not yet been reported. Thus, we here investigated the physiological activity and effects of omega-7 in hydrogen peroxide $\left(\mathrm{H}_{2} \mathrm{O}_{2}\right)$-treated human keratinocyte cells. Our results suggested that natural resource of omega-7 is helpful for collagen regeneration and elasticity through SIRT1 activation.

\section{Materials and methods}

\section{Cell culture}

Human keratinocyte cell lines (HaCaT) (ATCC, Rockville, MD, USA) were kept in Dulbecco's modified Eagle medium (DMEM) (HyClone, Logan, UT, USA) containing $10 \%$ FBS (Gibco, CA, USA) and 1\% antibiotics (penicillin [100 U/mL], streptomycin [100 $\mathrm{g} / \mathrm{mL}]$ ) (Sigma-Aldrich, St. Louis, MO, USA) in a $37^{\circ} \mathrm{C}$ humidified atmosphere with $5 \% \mathrm{CO}_{2}$. Cell culture media was changed every 2-3 days. Cells were subcultured in 100-mm dishes (Nunc, Rochester, NY, USA) $24 \mathrm{~h}$ before treatment. Omega-7 (Sigma-Aldrich) was dissolved in $99.5 \%$ ethanol and stocked at $-80^{\circ} \mathrm{C}$. Every aliquot was used not more than two times.

\section{Cell viability assay}

Cell viability was measured using a 3-(4,5-dimethylthiazol2-yl)-2,5-diphenyltetrazolium bromide (MTT) assay kit from sigma [14]. HaCaT cells were plated at a density of $2 \times 10^{4}$ cells/well in 48-well plates (Nunc, NY, USA). When cell confluency was $80 \%$ after incubation for $24 \mathrm{~h}$, cells were treated with omega-7 (1-20 $\mu \mathrm{g} / \mathrm{mL})$ or $\mathrm{H}_{2} \mathrm{O}_{2}$ (0.1-1 mM) for $24 \mathrm{~h}$. We also investigated the effects of a 1-h pretreatment with omega-7 $(5-20 \mu \mathrm{g} / \mathrm{mL})$ on $\mathrm{HaCaT}$ cell viability treated with $1 \mathrm{mM} \mathrm{H}_{2} \mathrm{O}_{2}$ for $24 \mathrm{~h}$. After incubation, $10 \mu \mathrm{L}$ of the MTT solution $(500 \mu \mathrm{g} / \mathrm{mL})$ was added to each well, and cells were incubated for $2 \mathrm{~h}$ in $37{ }^{\circ} \mathrm{C}$ humidified incubator without light. Absorbance was determined at $540 \mathrm{~nm}$ using a microplate reader (BioTek, Winooski, VT, USA).

\section{Intracellular reaction oxygen species (ROS) production assay}

Intracellular ROS production was determined by fluorescence assay using dichlorofluorescin diacetate (DCF-DA; Invitrogen, Carlsbad, CA, USA). The ROS production was determined using the method described by Gerber and Dubery [15] with slight modification. HaCaT cells were plated in 48 -well plates at a density of $4 \times 10^{5}$ cell/well. When cell confluency was $80 \%$ after incubation for $24 \mathrm{~h}$, we investigated the effect of a 1-h pretreatment with omega-7 $(20 \mu \mathrm{g} / \mathrm{mL})$ on ROS production in HaCaT cells treated with $1 \mathrm{mM} \mathrm{H}_{2} \mathrm{O}_{2}$ and/or sirtinol $(10 \mu \mathrm{M})$ for $24 \mathrm{~h}$. After incubation, cells were washed with PBS and stained with $10 \mu \mathrm{M}$ DCF-DA in PBS for $20 \mathrm{~min}$ in the dark at $37{ }^{\circ} \mathrm{C}$. Fluorescence was determined with an excitation wavelength $530 \mathrm{~nm}$.

\section{Preparation of nuclear extracts}

To prepare nuclear extracts, HaCaT cells were plated in 6 -well plates at a density of $5 \times 10^{6}$ cell/well. We investigated the effect of a 1-h pretreatment with omega-7 $(20 \mu \mathrm{g} / \mathrm{mL})$ on ROS production in $\mathrm{HaCaT}$ cells treated with $1 \mathrm{mM} \mathrm{H}_{2} \mathrm{O}_{2}$ and/or sirtinol $(10 \mu \mathrm{M})$ for $24 \mathrm{~h}$. After washing the treated cells three times with PBS, the cells were collected, pelleted by centrifugation, and lysed in buffer containing $10 \mathrm{mM}$ HEPES ( $\mathrm{pH} 7.8$ ), $2 \mathrm{mM} \mathrm{MgCl}_{2}$, $1 \mathrm{M}$ DTT, $0.1 \mathrm{mM}$ EDTA, $0.1 \mathrm{mM}$ PMSF, and protease inhibitor for $20 \mathrm{~min}$ at $4{ }^{\circ} \mathrm{C}$. Next, $10 \% \mathrm{NP}-40$ was added for $15 \mathrm{~s}$, and the cells were centrifuged at 12,000 rpm for $20 \mathrm{~min}$ at $4{ }^{\circ} \mathrm{C}$. After centrifugation, the pellet was washed with PBS and resuspended in nuclear extraction buffer containing $20 \mathrm{mM}$ HEPES (pH 7.9), $1.5 \mathrm{mM} \mathrm{MgCl}_{2}$, $400 \mathrm{mM} \mathrm{NaCl}, 1 \mathrm{mM}$ EDTA, $1 \mathrm{mM}$ DTT, $1 \mathrm{mM}$ PMSF, and protease inhibitor cocktail and incubated on ice for $30 \mathrm{~min}$. After incubation, the nuclear extract was prepared by centrifugation at $12,000 \mathrm{rpm}$ for $15 \mathrm{~min}$ at $4{ }^{\circ} \mathrm{C}$. The protein concentrations of extracts were determined using a commercial kit (Bio-Rad Laboratories, Hercules, CA, USA). 


\section{Western blotting}

For Western blotting, cells were treated in the same manner as for measuring viability and ROS and preparing nuclear extracts. Total proteins from HaCaT cell lysates were subjected to sodium dodecyl sulfate-polyacrylamide gel electrophoresis using $12 \%$ gels, transferred to PVDF membranes (BioRad, Hercules, CA, USA), and blocked with 5\% skim milk in PBS, after which the membranes were incubated with a $1: 1000 \mathrm{v} / \mathrm{v}$ dilution of primary antibodies against COX-2 and PCOL1 (Santa cruz Biotechnology, Santa Cruz, CA, USA); $\beta$-actin and NF- $\kappa \mathrm{B}$ (Cell signaling, Danvers, MA, USA); and PGE2, histone H3, MMP-1, and elastin (Abcam, Cambridge, MA, USA) with $1 \%$ skim milk overnight at $4{ }^{\circ} \mathrm{C}$. After the Blots were washed, the membranes were next incubated with peroxidase-conjugated goat anti-rabbit IgG and goat anti-mouse IgG (1:5000 v/v, Millipore, CA, USA) for $1 \mathrm{~h}$ at room temperature. The immunoreactions were visualized using SuperSignal West Dura Extended Duration Substrate (Thermo Scientific, San Jose, CA, USA) and analyzed using a chemiImager analyzer (Alpha Innotech, San Leandro, CA, USA).

\section{Statistical analysis}

All experiments were carried out at least in triplicate, and results are presented as mean \pm SEM. The data were analyzed using Student's $t$ test (for two groups) and oneway ANOVA, and Tukey's test (for more than two groups). Differences with $P$ values $<0.05$ were considered statistically significant.

\section{Results}

\section{SIRT1 is up-regulated by omega-7 in HaCaT cells}

We first used MTT assays to assess the cytotoxicity of omega-7 in HaCaT cells. HaCaT cells were treated with omega-7 at various concentrations $(1,5,10$, and $20 \mu \mathrm{g} / \mathrm{mL})$ for $24 \mathrm{~h}$. Compared to control cells, omega-7 did not show any cytotoxic effects until a concentration of $20 \mu \mathrm{g} / \mathrm{mL}$ (Fig. 1A). We next evaluated the ability of omega-7 to regulate expression of SIRT1 in HaCaT cells and found that omega-7 increased SIRT1 expression in dose-dependent manner (Fig. 1B). Thus, these data confirmed that omega-7 is not cytotoxic up to a concentration of $20 \mu \mathrm{g} /$ $\mathrm{mL}$ in $\mathrm{HaCaT}$ cells and is able to up-regulate expression of SIRT1.
Omega-7 decreases oxidative stress, reduces MMP-1 expression, and up-regulates the expression of PCOL1 and elastin in $\mathrm{H}_{2} \mathrm{O}_{2}$-treated $\mathrm{HaCaT}$ cells

We first established the effects of oxidative stress in $\mathrm{HaCaT}$ cells. Cell viability was decreased by $40 \%$ after a 24-h treatment with $1 \mathrm{mM} \mathrm{H}_{2} \mathrm{O}_{2}$ (Fig. 2A). Based on these data, we used $1 \mathrm{mM} \mathrm{H}_{2} \mathrm{O}_{2}$ in all subsequent experiments. $\mathrm{HaCaT}$ cells pretreated with omega-7 exhibited significantly increased viability compared with cells treated with $\mathrm{H}_{2} \mathrm{O}_{2}$ alone (Fig. 2B). Next, to evaluate the effects of omega-7 on collagen regeneration, we measured levels of MMP-1, PCOL1, and elastin using three different concentrations of omega-7 in HaCaT cells treated with $1 \mathrm{mM}$ $\mathrm{H}_{2} \mathrm{O}_{2}$. The expression of MMP-1 in cells treated with $\mathrm{H}_{2} \mathrm{O}_{2}$ alone was significantly increased, whereas co-treatment with omega-7 significantly decreased expression of MMP1 induced by $\mathrm{H}_{2} \mathrm{O}_{2}$ (Fig. 2C). In addition, the expression of PCOL1 and elastin in cells treated with $\mathrm{H}_{2} \mathrm{O}_{2}$ alone was significantly decreased, whereas omega-7 significantly increased the expression of both in a dose-dependent manner (Fig. 2D, E). Thus, these results suggest that omega-7 rescues collagen regulation and improves elasticity in $\mathrm{H}_{2} \mathrm{O}_{2}$-treated $\mathrm{HaCaT}$ cells.

\section{Omega-7 down-regulates ROS production and inflammatory factors induced by $\mathrm{H}_{2} \mathrm{O}_{2}$ in $\mathrm{HaCaT}$ cells}

We next investigated the association between omega-7 $(20 \mu \mathrm{g} / \mathrm{mL})$ and SIRT1 on $\mathrm{H}_{2} \mathrm{O}_{2}$-induced NF- $\kappa \mathrm{B}$, ROS, $\mathrm{COX}-2$, and $\mathrm{PGE}_{2}$ expression in the presence of sirtinol, an inhibitor of SIRT1 $(10 \mu \mathrm{M})$. Omega-7 significantly increased the protein expression of SIRT1, which was decreased by $\mathrm{H}_{2} \mathrm{O}_{2}$ exposure in $\mathrm{HaCaT}$ cells. Sirtinol significantly counteracted the inhibitory effect of omega-7 on $\mathrm{H}_{2} \mathrm{O}_{2}$-induced SIRT1 expression (Fig. 3A). On the other hand, omega-7 significantly decreased the expression of $\mathrm{H}_{2} \mathrm{O}_{2}$-induced expression of NF- $\kappa \mathrm{B}, \mathrm{ROS}, \mathrm{COX}-2$, and $\mathrm{PGE}_{2}$. Sirtinol significantly counteracted the suppressive effects of omega-7 on $\mathrm{H}_{2} \mathrm{O}_{2}$-induced NF- $\kappa \mathrm{B}, \mathrm{ROS}, \mathrm{COX}-2$, and $\mathrm{PGE}_{2}$ (Fig. 3B-E). These results indicate that omega-7 has a protective effect on $\mathrm{H}_{2} \mathrm{O}_{2}$-induced cell damage as well as anti-inflammatory effects in $\mathrm{HaCaT}$ cells, mediated by activation of SIRT1.

\section{Omega-7 increases collagen regeneration through SIRT1 activation}

We confirmed the association between omega-7 (20 $\mu \mathrm{g} /$ mL) and SIRT1 with MMP-1, PCOL1, and elastin expression in $\mathrm{H}_{2} \mathrm{O}_{2}$-treated $\mathrm{HaCaT}$ cells using sirtinol (10 $\mu \mathrm{M})$. Omega-7 significantly diminished $\mathrm{H}_{2} \mathrm{O}_{2}$-induced 


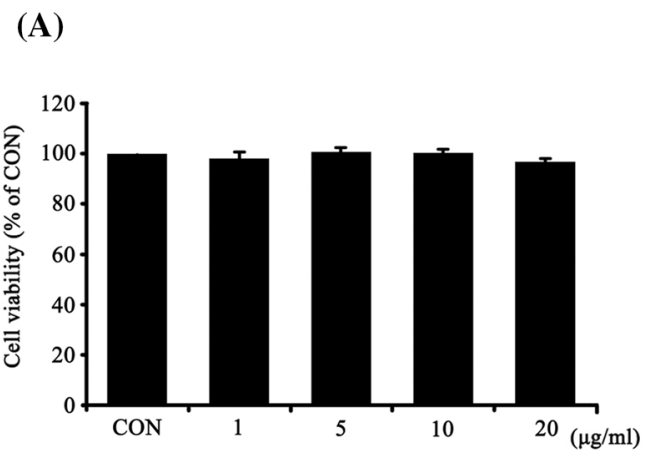

Fig. 1 Cytotoxicity and SIRT1 expression of omega-7 in HaCaT cells. (A) Viability of $\mathrm{HaCaT}$ cells after treatment with increasing concentrations of omega-7 (1-20 $\mu \mathrm{g} / \mathrm{mL})$ for $24 \mathrm{~h}$. (B) SIRT1 protein expression was determined in cells treated with increasing

(B)

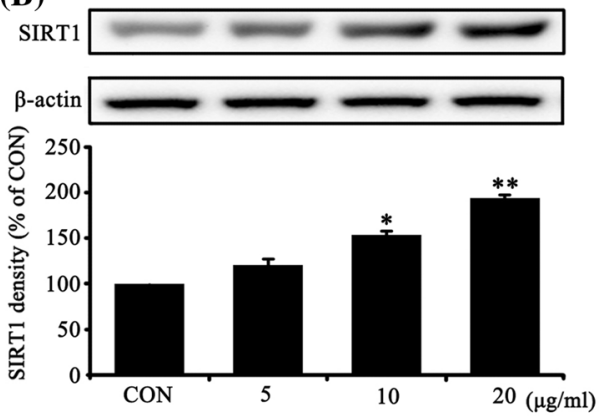

concentrations of omega-7 (1-20 $\mu \mathrm{g} / \mathrm{mL})$ for $24 \mathrm{~h}$. Data are expressed as mean $\pm \mathrm{SEM}$ of three independent experiments. $* P<0.05$ and $* * P<0.01$ versus $\mathrm{CON}$

(B)
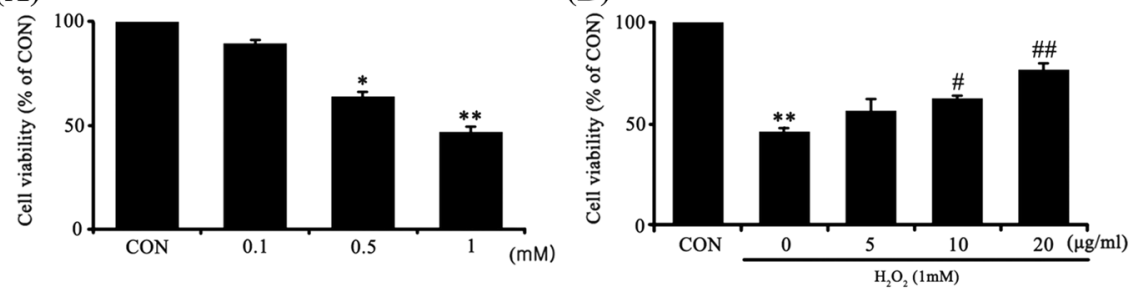

(C)

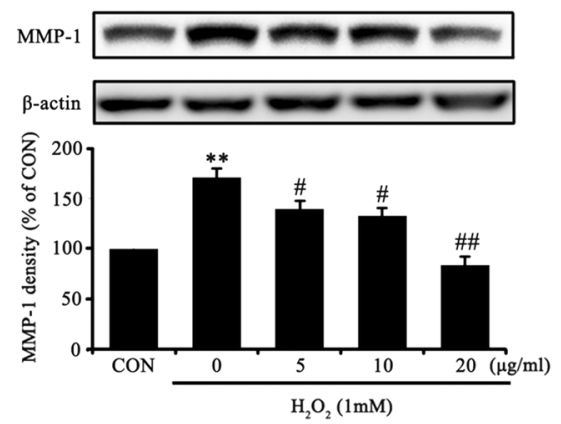

(D)

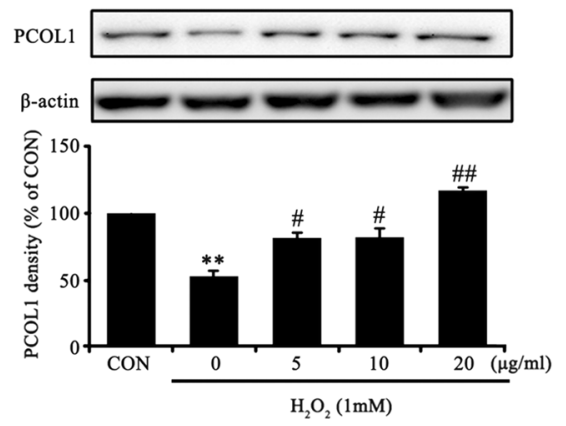

(E)

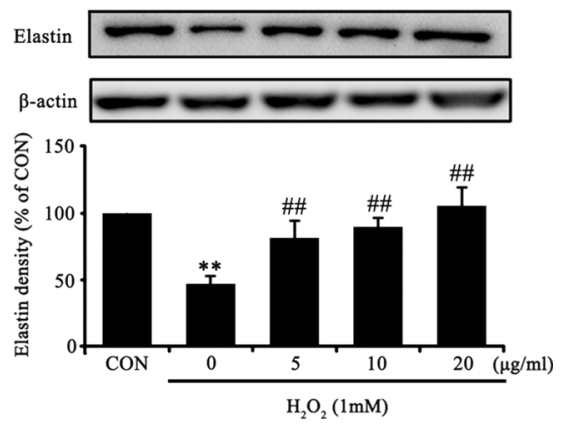

Fig. 2 Effects of omega-7 on cell viability, collagen regeneration, and elasticity factor expression against oxidative stress in $\mathrm{H}_{2} \mathrm{O}_{2-}$ treated $\mathrm{HaCaT}$ cells. (A) Viability of $\mathrm{HaCaT}$ cells after treatment with increasing concentrations of $\mathrm{H}_{2} \mathrm{O}_{2}(0.1-1 \mathrm{mM})$ for $24 \mathrm{~h}$. (B) $\mathrm{HaCaT}$ cells after treatment with $1 \mathrm{mM} \mathrm{H}_{2} \mathrm{O}_{2}$ for $24 \mathrm{~h}$ after pretreatment with

MMP-1 expression in HaCaT cells. In addition, sirtinol significantly reversed the inhibitory effects of omega-7 on $\mathrm{H}_{2} \mathrm{O}_{2}$-induced MMP-1 expression (Fig. 4A). On the other hand, omega-7 significantly increased the expression of PCOL1 and elastin, which was decreased by $\mathrm{H}_{2} \mathrm{O}_{2}$ exposure in $\mathrm{HaCaT}$ cells. Sirtinol also significantly counteracted the ability of omega- 7 to rescue the $\mathrm{H}_{2} \mathrm{O}_{2}$-mediated decrease in PCOL1 and elastin expression (Fig. 4B, C). Together, these results showed that activation of SIRT1 by omega-7 significantly decreases $\mathrm{H}_{2} \mathrm{O}_{2}$-induced MMP-1. In addition, the activation of SIRT1 by omega-7 significantly increased PCOL1 and elastin in $\mathrm{H}_{2} \mathrm{O}_{2}$-treated $\mathrm{HaCaT}$ cells. omega-7 (1-20 $\mu \mathrm{g} / \mathrm{mL})$ for $1 \mathrm{~h}$. (D-E) Whole cell lysates were subjected to Western blot analysis to evaluate MMP-1, PCOL1, and elastin expression. ${ }^{*} P<0.05, * * P<0.01$ versus $\mathrm{CON},{ }^{\#} P<0.05$, ${ }^{\# \#} P<0.01$ versus $\mathrm{H}_{2} \mathrm{O}_{2}$

\section{Discussion}

Palmitoleic acid (16:1, Cis-9-hexadecenoic acid) is an omega-7 fatty acid present in animals such as cold-water fish and plants such as macadamia and sea buckthorn [8]. Omega-7 fatty acids have been shown to have beneficial effects as health supplements to improve cardiovascular disease risk and increase insulin sensitivity [9]. In the present study, we showed that omega-7 inhibits inflammatory factors and rescues collagen production through activation of SIRT1 and subsequent downregulation of NF$\kappa \mathrm{B}$ and MMP-1 in $\mathrm{H}_{2} \mathrm{O}_{2}$-treated $\mathrm{HaCaT}$ cells. SIRT1 is the 

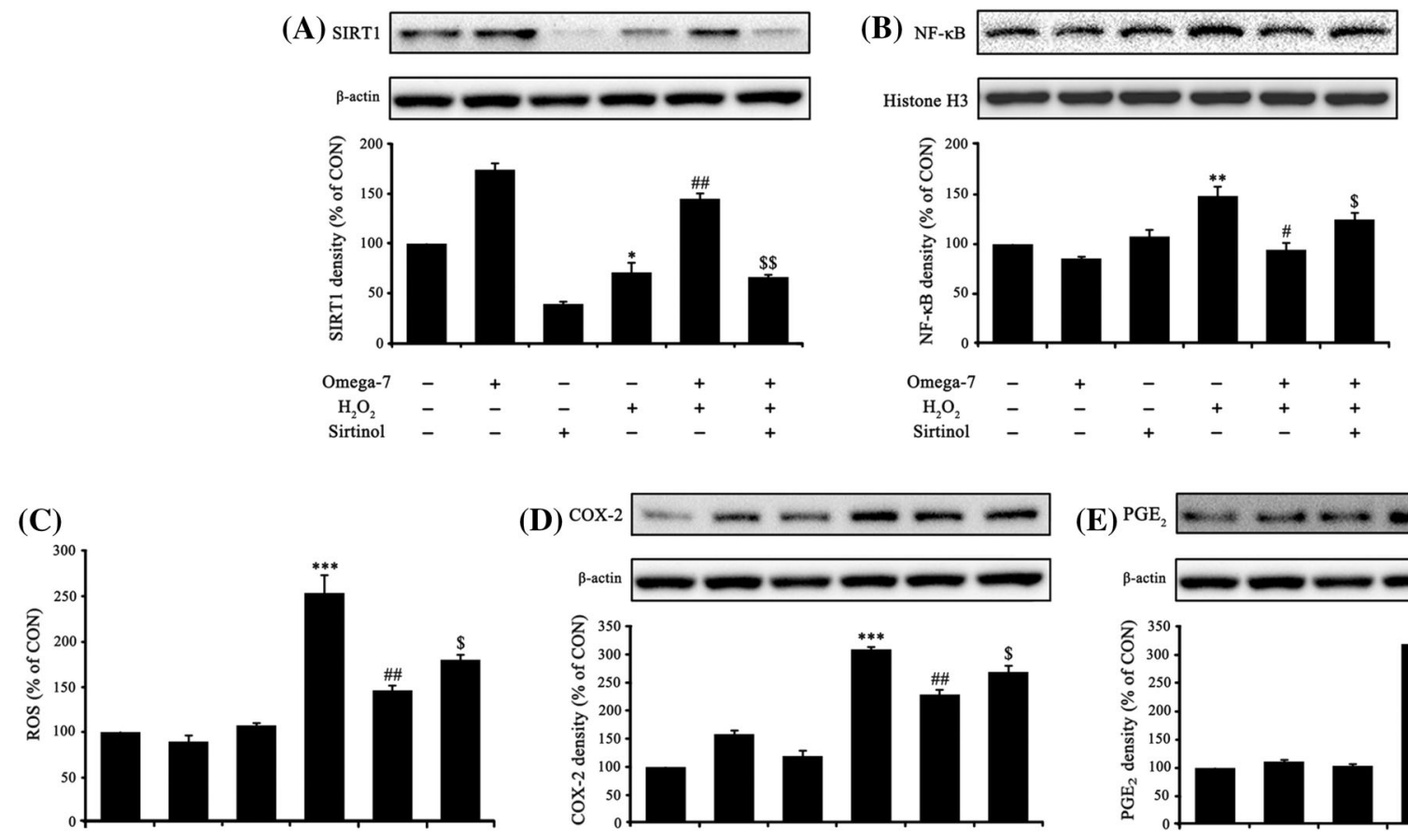

(D) $\operatorname{cox}-2^{\mathrm{m}}-\mathrm{m}-\mathrm{m}$

(E) $\mathrm{PGE}_{2} \ldots+\cdots$
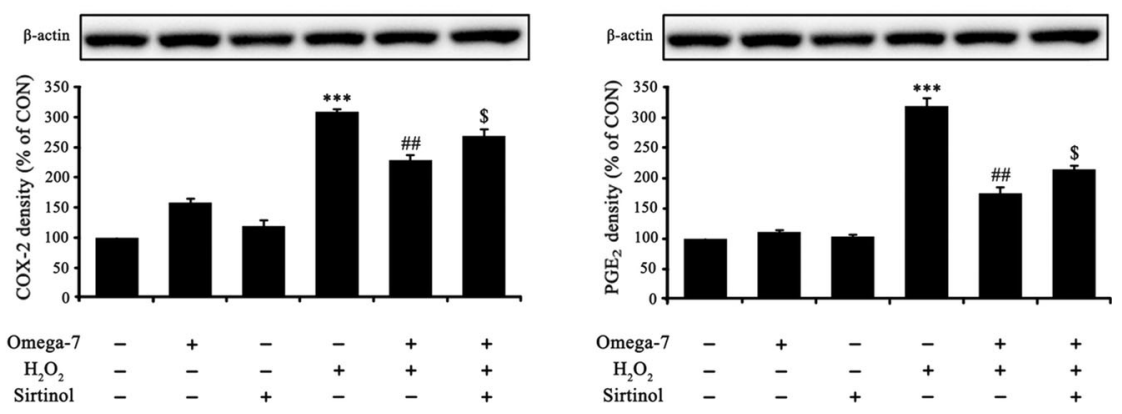

Fig. 3 Effect of omega-7 on the activation of SIRT1 and inflammatory factors in $\mathrm{HaCaT}$ cells co-treated with $\mathrm{H}_{2} \mathrm{O}_{2}$ and a SIRT1 inhibitor. HaCaT cells were pretreated for $1 \mathrm{~h}$ with omega-7 $(20 \mu \mathrm{g} /$ $\mathrm{mL}$ ), followed by incubation with $1 \mathrm{mM} \mathrm{H}_{2} \mathrm{O}_{2}$ and/or sirtinol $(10 \mu \mathrm{M})$ for $24 \mathrm{~h}$. (A, D, E) Whole cell lysates were subjected to Western blot analysis to evaluate expression of SIRT1, COX-2, and $\mathrm{PGE}_{2}$. (B) Nuclear extracts were prepared for Western blot analysis of
NF- $\kappa$ B. (C) HaCaT cells were pretreated with omega-7 $(1-20 \mu \mathrm{g} / \mathrm{mL})$ for $1 \mathrm{~h}$, followed by $\mathrm{H}_{2} \mathrm{O}_{2}(1 \mathrm{mM})$ and/or sirtinol $(10 \mu \mathrm{M})$ for $24 \mathrm{~h}$, after which ROS levels were evaluated by DCF-DA. Data are expressed as the mean \pm SEM of three independent experiments, $* P<0.05, * * P<0.01$ and $* * P<0.001$ versus $\mathrm{CON},{ }^{\#} P<0.05$, ${ }^{\# \#} P<0.01$ and ${ }^{\# \# \#} P<0.001$ versus $\mathrm{H}_{2} \mathrm{O}_{2}$ alone, ${ }^{\$} P<0.05$ and ${ }^{\$} \mathrm{P}<0.01$ versus omega-7 co-treated with $\mathrm{H}_{2} \mathrm{O}_{2}$
(A)

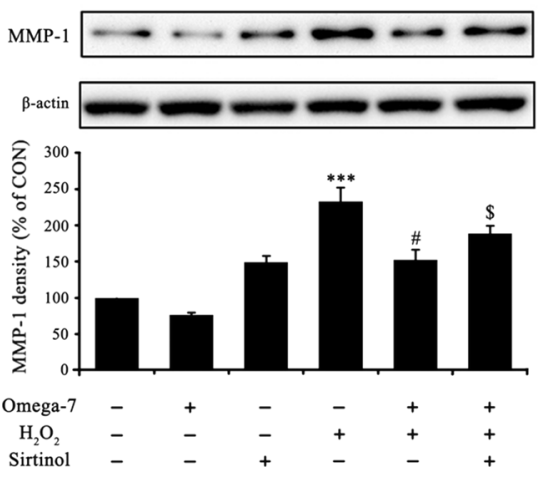

(B)

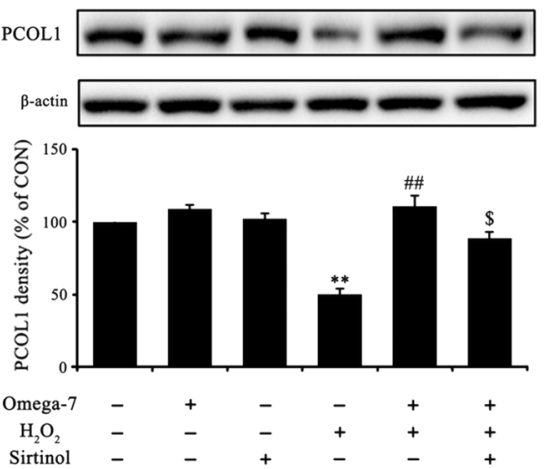

(C)

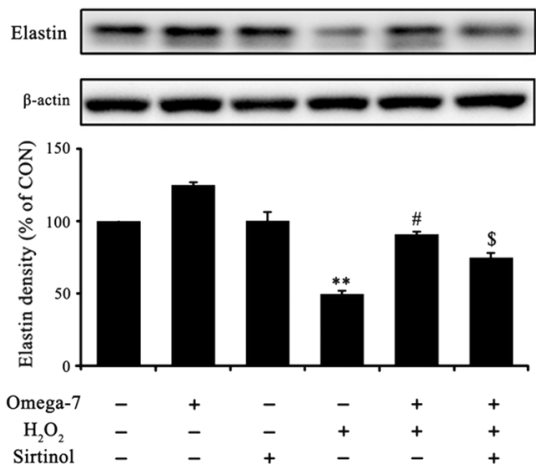

Fig. 4 Effect of omega-7 on activation of MMP-1, PCOL1, and elastin in $\mathrm{HaCaT}$ cells co-treated with $\mathrm{H}_{2} \mathrm{O}_{2}$ and a SIRT1 inhibitor. $\mathrm{HaCaT}$ cells were pretreated for $1 \mathrm{~h}$ with omega-7 $(20 \mu \mathrm{g} / \mathrm{mL})$, followed by treatment with $1 \mathrm{mM} \mathrm{H}_{2} \mathrm{O}_{2}$ and/or sirtinol $(10 \mu \mathrm{M})$ for $24 \mathrm{~h}$. (A-C) Whole cell lysates were subjected to Western blot

mainly studied member of the sirtuin protein family, which are conserved $\mathrm{NAD}^{+}$-dependent deacetylases [16]. SIRT1 has been showed to play a key role in a variety of physiological activity associated with aging [17]. Consistently, we showed that omega-7 increases SIRT1 activation in a analysis to evaluate the expression of MMP-1, PCOL1, and elastin. Data are expressed as the mean \pm SEM of three independent experiments, $* * P<0.01$ and $* * * P<0.001$ versus $\mathrm{CON},{ }^{\#} P<0.05$ and ${ }^{\# \#} P<0.01$ versus $\mathrm{H}_{2} \mathrm{O}_{2}$ alone, ${ }^{\$} P<0.05$ versus omega-7 cotreated with $\mathrm{H}_{2} \mathrm{O}_{2}$

dose-dependent manner, and that this activation could be decreased by the SIRT1 inhibitor sirtinol (Figs. 1A, 3A).

External stimuli such as toxins, heat, and UVB are major skin irritants that are all capable of generating oxidative stress in skin [18]. Excessive ROS production during 
oxidative stress interrupts the maintenance of normal skin functions by increasing inflammation and inhibiting collagen synthesis, ultimately promoting skin aging [19]. In particular, ROS up-regulate MMP-1 and down-regulate factors involved in collagen synthesis in damaged skin cells [20]. Among a number of different collagenases, MMP-1 is the major player, serving primarily to cleave type I collagen. In this way, MMP-1 can cause disruption on the balance between synthesis and degradation of collagen and plays a key role in the formation of wrinkles and decreased elasticity [21]. In this study, we showed that omega-7 significantly decreased the expression of MMP-1 while increasing the expression of PCOL1 and elastin (Fig. 2C-E). These results indicate that omega-7 rescues collagen synthesis by inhibiting MMP-1 activation.

$\mathrm{NF}-\kappa \mathrm{B}$ is a major transcription factor involved in the inflammatory response [22]. NF- $\kappa \mathrm{B}$ is located in the cytosol in an inactivated state and, upon stimulation by ROS, translocates to the nucleus to regulate the expression of inflammatory proteins such as COX-2 and chemical regulators such as $\mathrm{PGE}_{2}$, together leading to accelerated skin aging [23]. A recent study demonstrated that SIRT1 also plays a critical role as a suppressor of the NF- $\mathrm{kB}$ signaling pathway by deacetylating NF- $\kappa B$ [24]. In this way, inhibition of NF- $\kappa \mathrm{B}$ signaling pathway by SIRT1 activation decreases pro-inflammatory cytokines and gene products involved in inflammation and apoptosis [25]. In the present study, we confirmed whether omega-7-mediated activation of SIRT1 could regulate oxidative stress and inflammation in $\mathrm{H}_{2} \mathrm{O}_{2}$-treated $\mathrm{HaCaT}$ cells. Omega-7 up-regulated SIRT1 expression in $\mathrm{H}_{2} \mathrm{O}_{2}$-treated $\mathrm{HaCaT}$ cell, whereas the increased level of SIRT1 was reversed by sirtinol, a specific SIRT1 inhibitor. These results show that omega-7 exerts its effects primarily by increasing SIRT1 activation (Fig. 3A). Likewise, omega-7 inhibits ROS production and inflammatory factors such as NF- $\mathrm{\kappa B}, \mathrm{COX}$ 2, and $\mathrm{PGE}_{2}$ in $\mathrm{H}_{2} \mathrm{O}_{2}$-treated $\mathrm{HaCaT}$ cells. As expected, inhibition of ROS production and inflammation factors was reversed by co-treatment with sirtinol (Fig. 3B-E). Importantly, these results suggest that the increase in SIRT1 expression by omega-7 was account for the antiinflammatory effects of omega-7 in $\mathrm{H}_{2} \mathrm{O}_{2}$-treated $\mathrm{HaCaT}$ cells. Lastly, SIRT1 can accelerate the decrease in MMP-1 expression though deacetylation of NF- $\kappa B$ [26]. Taken together, our results showed that omega-7 decreases MMP1 expression and increases PCOL1 and elastin expression in $\mathrm{H}_{2} \mathrm{O}_{2}$-treated $\mathrm{HaCaT}$ cells by activating SIRT1, and that these effects could be reversed by a SIRT1 inhibitor (Fig. 4A-C).

In conclusion, our results suggest that omega-7 has antiinflammatory effects in $\mathrm{HaCaT}$ cells, where it promotes collagen regeneration in the presence of $\mathrm{H}_{2} \mathrm{O}_{2}$-induced cytotoxicity. The anti-inflammatory effects of omega-7 appear to be mediated through SIRT1 activation. Our results provide strong evidence for omega-7 as a functional food for promoting skin health to prevent aging.

Acknowledgments This research was supported by Vitech Co., Ltd.

\section{References}

1. Halliwell B (2012) Free radicals and antioxidants: updating a personal view. Nutr Rev 70(5):257-265

2. Podhaisky HP, Riemschneider S, Wohlrab W (2002) UV light and oxidative damage of the skin. Pharmazie 57(1):30-33

3. Ozben T (2007) Oxidative stress and apoptosis: impact on cancer therapy. J Pharm Sci 96(9):2181-2196

4. Pillai S, Oresajo C, Hayward J (2005) Ultraviolet radiation and skin aging: roles of reactive oxygen species, inflammation and protease activation, and strategies for prevention of inflammation-induced matrix degradation - a review. Int $\mathrm{J}$ Cosmet Sci 27(1):17-34

5. Rahman I, Kinnula VL, Gorbunova V, Yao H (2012) SIRT1 as a therapeutic target in inflammaging of the pulmonary disease. Prev Med 54(Suppl):S20-S28

6. Yeung F, Hoberg JE, Ramsey CS, Keller MD, Jones DR, Frye RA (2004) Modulation of NF-kappaB-dependent transcription and cell survival by the SIRT1 deacetylase. EMBO J 23(12):2369-2380

7. Cao C, Lu S, Kivlin R, Wallin B, Card E, Bagdasarian A (2009) SIRT1 confers protection against UVB- and $\mathrm{H} 2 \mathrm{O} 2$-induced cell death via modulation of p53 and JNK in cultured skin keratinocytes. J Cell Mol Med 13(9b):3632-3643

8. Maguire LS, O'Sullivan SM, Galvin K, O'Connor TP, O'Brien NM (2004) Fatty acid profile, tocopherol, squalene and phytosterol content of walnuts, almonds, peanuts, hazelnuts and the macadamia nut. Int J Food Sci Nutr 55(3):171-178

9. Anderson MM, Hazen SL, Hsu FF, Heinecke JW (1997) Human neutrophils employ the myeloperoxidase-hydrogen peroxidechloride system to convert hydroxy-amino acids into glycolaldehyde, 2-hydroxypropanal, and acrolein. A mechanism for the generation of highly reactive alpha-hydroxy and alpha, betaunsaturated aldehydes by phagocytes at sites of inflammation. J Clin Invest 99(3):424-432

10. Souza CO, Teixeira AA, Lima EA, Batatinha HA, Gomes LM, Carvalho-Silva M (2014) Palmitoleic acid (n-7) attenuates the immunometabolic disturbances caused by a high-fat diet independently of PPARalpha. Mediat Inflamm 2014:582197

11. Inoue $T$, Tanaka $M$, Masuda $S$, Ohue-Kitano R, Yamakage $H$, Muranaka K (2017) Omega-3 polyunsaturated fatty acids suppress the inflammatory responses of lipopolysaccharide-stimulated mouse microglia by activating SIRT1 pathways. Biochim Biophys Acta 1862(5):552-560

12. Saboori S, Koohdani F, Nematipour E, Yousefi Rad E, SaboorYaraghi AA, Javanbakht MH (2016) Beneficial effects of omega3 and vitamin E coadministration on gene expression of SIRT1 and PGC1alpha and serum antioxidant enzymes in patients with coronary artery disease. Nutr Metab Cardiovasc Dis 26(6):489-494

13. Lim JH, Gerhart-Hines Z, Dominy JE, Lee Y, Kim S, Tabata M (2013) Oleic acid stimulates complete oxidation of fatty acids through protein kinase A-dependent activation of SIRT1PGC1alpha complex. J Biol Chem 288(10):7117-7126

14. Grela E, Zabek A, Grabowiecka A (2015) Interferences in the optimization of the MTT assay for viability estimation of proteus mirabilis. Avicenna J Med Biotechnol 7(4):159-167 
15. Gerber IB, Dubery IA (2003) Fluorescence microplate assay for the detection of oxidative burst products in tobacco cell suspensions using $2^{\prime}, 7^{\prime}$-dichlorofluorescein. Methods Cell Sci 25(3-4):115-122

16. Dali-Youcef N, Lagouge M, Froelich S, Koehl C, Schoonjans K, Auwerx J (2007) Sirtuins: the 'magnificent seven', function, metabolism and longevity. Ann Med 39(5):335-345

17. Chung S, Yao H, Caito S, Hwang JW, Arunachalam G, Rahman I (2010) Regulation of SIRT1 in cellular functions: role of polyphenols. Arch Biochem Biophys 501(1):79-90

18. Yuan J, Murrell GA, Trickett A, Wang MX (2003) Involvement of cytochrome c release and caspase- 3 activation in the oxidative stress-induced apoptosis in human tendon fibroblasts. Biochim Biophys Acta 1641(1):35-41

19. Babior BM (2000) Phagocytes and oxidative stress. Am J Med 109(1):33-44

20. Jung HY, Shin JC, Park SM, Kim NR, Kwak W, Choi BH (2014) Pinus densiflora extract protects human skin fibroblasts against UVB-induced photoaging by inhibiting the expression of MMPs and increasing type I procollagen expression. Toxicol Rep 1:658-666

21. Park CH, Lee MJ, Kim JP, Yoo ID, Chung JH (2006) Prevention of UV radiation-induced premature skin aging in hairless mice by the novel compound Melanocin A. Photochem Photobiol 82(2):574-578

22. Piva R, Belardo G, Santoro MG (2006) NF-kappaB: a stressregulated switch for cell survival. Antioxid Redox Signal 8(3-4):478-486

23. Feldman M, Taylor P, Paleolog E, Brennan FM, Maini RN (1998) Anti-TNF alpha therapy is useful in rheumatoid arthritis and Crohn's disease: analysis of the mechanism of action predicts utility in other diseases. Transplant Proc 30(8):4126-4127

24. Lee JH, Song MY, Song EK, Kim EK, Moon WS, Han MK (2009) Overexpression of SIRT1 protects pancreatic beta-cells against cytokine toxicity by suppressing the nuclear factor-kappaB signaling pathway. Diabetes 58(2):344-351

25. Bazan NG (2007) Omega-3 fatty acids, pro-inflammatory signaling and neuroprotection. Curr Opin Clin Nutr Metab Care 10(2):136-141

26. Annabi B, Lord-Dufour S, Vezina A, Beliveau R (2012) Resveratrol targeting of carcinogen-induced brain endothelial cell inflammation biomarkers MMP-9 and COX-2 is Sirt1-independent. Drug Target Insights 6:1-11 